\title{
CHARACTERISTICS OF THE URBAN ENVIRONMENT IN AND ISSUES IN THE CREATION OF A GREEN SHIELD AROUND THE CITY OF MAKHACHKALA, DAGESTAN, RUSSIA
}

Nikolay Alexandrovich Sluka ${ }^{* 1}$, Amil Zabitovich Sarkarov*2, Eldar Magomedovich Eldarov *2

"Lomonosov Moscow State University, Moscow, Russian Federation

"Dagestan State University, Makhachkala, Russian Federation

\begin{abstract}
This paper addresses issues of beautifying the capital of Dagestan, Makhachkala, and boosting nature conservation in that city. An insight is provided into the following characteristics of the city's socio-economic and environmental development: the prevalence of haphazard rather than consistent patterns in the development of the living environment of Makhachkala residents and an extreme lack of funding for nature conservation activities. The four key sites within Makhachkala's potential "green shield" are (1) Eltav Forest in the northwest; (2) the Caspian Sea with its sandy beaches in the northeast; (3) Lake Ak-Gel in the southeast; (4) Tarki-Tau Mountain in the southwest. The need is stressed for creative management decisions that will take full account of the ethnocultural and ethnopsychological characteristics of the city's urban environment.
\end{abstract}

Keywords: Dagestan, Makhachkala, sustainable development, nature conservation, green shield, city's geo-environmental landmarks

\section{Introduction}

While many large cities are places with serious social, economic, and environmental issues, many of them are also generators of innovation and

1 Corresponding author: N.A. Sluka, Faculty of Geography, Moscow State University. M.V. Lomonosov, Russia, Makhachkala; e-mail: sluka2011@yandex.ru 
drivers for achievement of the Sustainable Development Goals (SDGs), a program of action for the period 2016-2030 adopted by the United Nations General Assembly to help tackle critical global challenges and improve the economic and social well-being of people around the world. In the context of this program, on January 1, 2017, the Russian government brought into force a special law covering the creation around cities of forest-and-park green belts, areas with limited natural resource use, popularly known as the "green shield law" (Federal Law No. 353-FZ On Forest-and-Park Green Zones of July 3, 2016). A green shield is an environmentally effective area that can be developed through the establishment of special nature conservation regimes and the creation of a forest-and-park belt on areas occupied by forests, waterbodies, and other natural sites that perform environment-forming, nature conservation, ecological, sanitary-hygienic, and recreational functions ${ }^{2}$.

So far, relevant ordinances on the creation of forest-and-park green belts around large cities have been adopted in 63 of Russia's constituent regions. This includes the Republic of Dagestan, whose capital, Makhachkala, has been ahead in population increase of many of its counterparts in Russia ${ }^{3}$ (Bagomedov, 2013; Chernyshov, 2012). Specifically, whereas in the period 1979-1989 its population rose from 251,000 to 315,000 , i.e. around $26 \%$, in the intercensal periods 1989 2002 and $2002-2010$ it rose from 337,000 to 378,000 (12\%) and from 378,000 to $697,000(84 \%)$, respectively ${ }^{4,5}$ (Ionov, 2020).

Factors such as the extensive natural reproduction of its population and a massive migration from the countryside to Makhachkala, coupled with extensive residential construction, have led to the capital virtually swallowing up Kaspiysk, its satellite city, and many of the nearby townships. This has led to the emergence of the Makhachkala agglomeration - one of the largest in the south of Russia and the largest in the North Caucasian Federal District (Zubarevich, Safronov 2019). Based on estimates from Moscowbased geographers E.V. Antonov and A.G. Makhrova, the metropolis had a population of 1.2 million as early as 2018, with the figure growing by 94,000 in the period 2010-2018 alone (Antonov, Makhrova, 2019).

\footnotetext{
2 Gosduma prinyala vo vtorom i tret'yem chtenii zakonoproyekt ONF o «zelonom shchite» [Elektronnyy resurs] // Obshcherossiyskiy narodnyy front. 17.06.2016. URL: https:/ / onf.ru/2016/06/17/gosduma-prinyala-vo-vtorom-i-tretem-chtenii-zakonoproektonf-o-zelenom-shchite/ (data obrashcheniya 20.08.2021).

3 Sovremennyye ekologicheskiye problemy Dagestana. Makhachkala: DGPU, 1994. $198 \mathrm{~s}$

4 Demograficheskiy yezhegodnik. 2002 god. Stat. sbornik. Makhachkala: Goskomstat RD, 2003. $192 \mathrm{~s}$.

5 Naseleniye SSSR: Po dannym Vsesoyuznoy perepisi naseleniya 1989 g. / Gos. komitet SSSR po statistike. Informatsionno-izdatel'skiy otdel. M.: Finansy i statistika, 1990. 45 s.
} 
Characteristics of the urban environment in and issues in the creation of a green shield around the city of Makhachkala, Dagestan, Russia

Judging by Makhachkala's medical-environmental and sanitaryhygienic performance, which has been covered openly starting somewhere in the late 1980's, there are reasonable grounds to state that the capital of Dagestan has virtually the entire spectrum of environment pollutants, with the concentration thereof on particular components at times reaching record levels ${ }^{6,7,8}$. Based on the latest environmental research, the last 10 years have witnessed a fivefold increase in cancer cases among Makhachkala residents, with a high risk of infectious diseases observed ${ }^{9,10}$. There is an obvious need to boost urban greening in the capital. Based on the standards of the World Health Organization, a metropolis such as Makhachkala ought to have no less than 50 square meters of forest and approximately 300 square meters of suburban forest per resident (Eldarov, 2020). In Makhachkala, these figures are currently much lower, and over the last three decades the city has posted a catastrophic decrease in them (Kotilko et al., 2019).

The above indicates the relevance and vital importance for Makhachkala of the objective of building a healthy living environment for its residents, including via the creation of a "green shield" around the city.

\section{Social-environmental characteristics of Makhachkala's urban environment}

As is the case with most other large cities, the environmental situation in Makhachkala tends to be influenced by the following four major groups of factors (which differ in genetic attributes): natural, urban planning, technicaleconomic, and sociocultural (Kirilovab and Makhrova, 2020; Sluka, Tikunov and Chereshnia, 2019).

\footnotetext{
6 Gosudarstvennyy doklad «O sanitarno-epidemiologicheskoy obstanovke v RD v 1995 godu» / Otv. red. E. YA. Omariyeva. Makhachkala, 1995. 114 s.

7 Gosudarstvennyy doklad «O sanitarno-epidemiologicheskoy obstanovke v RD v 2018 godu» / Otv. red. E. YA. Omariyeva. Makhachkala, 2019. 135 s.

8 Doklad o sostoyanii okruzhayushchey prirodnoy sredy Respubliki Dagestan v 2001 godu. Makhachkala: Izd-vo «Yupiter», 2002. 224 s.

Mediko-gigiyenicheskiy atlas Respubliki Dagestan / otv. red. E.YA. Omariyeva, E. M. El'darov. Makhachkala: Poligraf-servis, 2002. 132 s.

10 Pokazateli sostoyaniya zdorov'ya naseleniya RD v 2015 godu. Makhachkala: Minzdrav RD, 2016.317 s.33. Rybina YU. Gradonachal'nik popalsya na auktsione [Elektronnyy resurs] / / Kommersant». 07.11.2018. URL: https:/ / www.kommersant.ru/doc/3793286 (data obrashcheniya 20.08.2021).
} 
Natural and urban planning factors tend to have minimal change over time. Their conservative nature somewhat simplifies the development, organization, and implementation of nature conservation programs. However, underestimating their effect on the environmental situation may have far-reaching negative consequences. The essential natural and urban planning factors shaping Makhachkala's natural environment include the following:

- quite pronounced arid climatic conditions, with the rebuilding of disrupted biological communities, therefore, taking a long time;

- meagerness and overall poor condition of the city's greenery - its "lungs";

- the city being situated on a tract of open sand and an area of dry steppe that is worked for agricultural purposes, which, combined with frequent wind, is conducive to increased levels of suspended particulates in the air, as well as fraught with powerful dust storms;

- unstable level of the Caspian Sea, which requires that building in the littoral area be done having consideration for the natural phenomenon of seawater encroaching now and then onto the coast and resulting groundwater surges across much of the city;

- Makhachkala being situated on a narrow littoral plain, with TarkiTau Mountain on one side and the Caspian Sea on the other; as a result, the city is crossed by a significant portion of through transportation, numerous inter-district pipelines, and multiple power transmission lines;

- orographic and maritime barriers in the territorial development of the capital determining the city's elongated built-up area and the active degradation of the northern and southern green belts, which play a crucial role in protecting Makhachkala from dust storms;

- heavy short rains typical of the submontane areas, Tarki-Tau Mountain being a large water-collecting area, the city being situated on a narrow littoral lowland strip, and the city's poor storm drainage system as key factors contributing to occasional floods in it and its streets being polluted by effluents from sewage;

- in the area of urban development, a major issue being difficulty in forestalling landslides on the sides of Tarki-Tau Mountain; 
Characteristics of the urban environment in and issues in the creation of a green shield around the city of Makhachkala, Dagestan, Russia

- concern increasingly growing over the seismic danger posed by the erection of buildings and constructions, including multistoried ones, in the area as a result of multiple violations of aseismic construction regulations.

The need for nature conservation activity on the capital's periphery is dictated by a somewhat different set of issues. These areas have large tracts of land that are affected by irrational economic activity (e.g., impromptu landfills for municipal and construction solid waste, operation of sand pits, oil and gas production, etc.). What adds relevance to the objective of recultivating them is the rapid growth of Makhachkala's demoeconomic potential. A highly important issue is industrial solid waste disposal and the organization of areas for storage of toxic chemicals and burial of toxic industrial and medical waste.

A special group of issues is unwarranted land grabs and housing development in highly protected areas near the October Revolution Canal and the lakes Vuzovskoe, Ak-Gel, Makhachkalinskoe, Bolshoe Turali, and Maloe Turali. For many years, the capital's authorities have, in flagrant violation of urban land use legislation, granted entrepreneurs and commercial enterprises plots in school and kindergarten areas and areas housing healthcare facilities, just a stone's throw from busy highways or right under high-voltage power line cables.

Another issue of concern for the city is the poor environmental condition of most of the small watercourses within it. These watercourses currently act mainly as stormwater collectors; they are used for the disposal of industrial and municipal wastewater as well. The following streams have turned into this kind of collector in Makhachkala over time: a rivulet that used to run from the township of Tarki into Lake Ak-Gel; a rivulet named Talginka, which originates in a resort area of the same name; a rivulet named Ternair, which begins in the vicinity of the Separatorny Poselok microdistrict and ends at the beach in the Makhachkala-1 microdistrict.

When contrasted with the alarming condition of the city's water resources, some of its other environmental problems appear to remain somewhat under the radar. This in part is associated with the territorialdifferentiated nature of their manifestation. For instance, residents of Makhachkala's central districts, especially those situated along the major throughways converging here, are faced, along with significant noise 
pollution, with an environmental issue such as smothering smog in windless weather (Kotilko et al., 2019).

The negative effect of the above-mentioned and some other naturalgeographic and urban planning factors on the living environment of Makhachkala residents is augmented to a significant degree by the impact of technical-economic and sociocultural factors. In addition to impacting on the urban environment with a special force, these factors tend to be characterized by great diversity, relatively high mobility in time and space, and being amenable to regulatory control by humans.

Among the technical-economic factors influencing the current environmental situation in the capital of Dagestan, the most prominent are the following:

- overall poor condition of the city's material-technical base, testimony to which is its extremely low capital-to-labor ratio and power supply per person vis-à-vis other large cities in the Russian Federation; low level of mechanization and automation of production processes in the city;

- the city's flawed functional-sectoral structure, which is expressed in the significant imbalance across fields of specialization, production operations, and sectors (most importantly, manufacturing and services), which is affecting the city's entire economy;

- the city's industry, widely represented by environmentally unfavorable production operations, having a sectoral structure that is irrational in terms of natural resource use;

- many of the city's enterprises having outmoded plant and equipment;

- low share of highly skilled workers among the city's employed population; slow process of implementing innovative solutions, including effective nature conservation technologies.

No less diverse are the sociocultural factors, both internal and external.

Dagestan occupies a peripheral position in relation to Russia's center. Consequently, its capital may not expect to be given priority attention by the country's central government (Borodina, 2017). There is also the ethnopolitical factor - Makhachkala cannot compare to predominantly Slavic cities in the North Caucasus such as Rostov, Krasnodar, Novorossiysk, or Stavropol, 
Characteristics of the urban environment in and issues in the creation of a green shield around the city of Makhachkala, Dagestan, Russia

which, on average, have been 1.5-2 times ahead of Dagestan's capital in key economic and social indicators ${ }^{11}$ (Gadzhiyev, Rabadanov, Eldarov, 2017).

Poverty in Makhachkala is mainly due to rampant corruption among the city's officials. To be specific, over the last seven years, criminal prosecutions have been brought against as many as four top officials in the capital, with the mafia nicknames of the first two of them known widely among Makhachkala residents (Aliyev, 2018; Akhmedov, 2016; Kots, 2013; Sarkarov, 2017).

The fact that there have been a series of headline-making arrests of top officials in the capital stands as testimony to not only the success of the federal government's efforts to combat corruption but also to cruel interclan wars being waged in the republic. Among the most remarkable aspects of the political behavior of those in charge of major financial-political clans in Makhachkala and all of Dagestan is their ability to demonstrate in a most vivid manner their loyalty to the federal center, win the support of powerful protectors in Moscow, and engage in active interaction with the security apparatus - above all, the Federal Security Service.

Mistrust of corrupt officials has largely distanced the city's general public from a focus on resolving issues of organizing and beautifying the urban environment. No less pronounced has been the distancing of the city's public authorities from a focus on acting in the best interests of its residents.

The current state of the capital of Russia's southernmost polyethnic settlement is being reflected in all aspects of the life of its residents. At present, the development of its urban environment is characterized by a natural erosion of traditional rural culture among new settlers and at the same time a failure of typical templates of urban culture to be firmly adopted by them. Consequently, low levels of environmental culture and environmental literacy have become the city's calling card.

The above-mentioned issues in the governance of the city of Makhachkala provide an explanation for why some of its districts still have no piped water and gas, central heating, sewers, and stormwater diversion. A good example is Semender, a large housing development that has seen flagrant violations of basic construction and sanitary-hygienic standards and rules (e.g., garbage going uncollected for weeks, many stray dogs, cows

\footnotetext{
Doklad o sostoyanii okruzhayushchey prirodnoy sredy Respubliki Dagestan v 2001
} godu. Makhachkala: Izd-vo «Yupiter», 2002. 224 s. 
feeding on garbage, etc.). A combination of the above social-environmental factors is pretty much what has been behind the overall unsatisfactory condition of the capital's environment (Eldarov, 2020).

\section{Problems with key sites within the city's "green shield"}

The monitoring of the city's park areas has helped identify plots that will be included in the forest-and-park green belt around the city of Makhachkala - a total of 32 areas, with 15 of these having established boundaries and being cadastrally registered.

The combined area of the 15 cadastrally registered forest-and-park areas (inclusive of suburban plantings) is 4,899 hectares. The combined area of the city's internal plantings, which include greenery in parks, public gardens, alleys, stadiums, and streets, is around 380-390 hectares, i.e. around 5 square meters of greenery per resident (against a recommended standard of 20-30 square meters).

The boundaries have yet to be established for Lenin Komsomol Park, Fiftieth Anniversary of the October Revolution Park, a public garden on Gamidov Avenue, a public garden on Peter I Avenue across from Lake AkGel, City of Craftsmen Park, Suleiman Stalsky Boulevard, Khappalaev Alley in New Kyakhulai, Rodopa Boulevard, Friendship and Deputies Public Garden, Fazu Alieva Public Garden, Entrepreneurs Alley, and other areas.

According to a member of the Makhachkala City Council, a working committee on green plantings was recently established comprising some of the republic's top researchers and foresters. The committee has allegedly suggested cutting down $70 \%$ of the trees in Lenin Komsomol Park. The above-mentioned member of the City Council is of the view that greenification work in the city is not always conducted in an effective manner, a good example being the case of Akushinsky Avenue, where practically all of the greenery planted over the last 2-3 years is now gone. According to the official, while many of the recommendations proposed may be good, there is a need for a sound legal-and-regulatory framework for maintaining the city's green shield. Having one in place should help prevent inconsistent decision-making on such issues ${ }^{12}$.

Based on the results of a round-table discussion held by the Dagestan

12 Dagestan v autsayderakh po sozdaniyu zelonogo shchita [Elektronnyy resurs] // Gazeta «Chernovik». 02.06.2019. URL: https://chernovik.net/content/lenta-novostey/ dagestan-v-autsayderah-po-sozdaniyu-zelenogo-shchita (data obrashcheniya 20.08.2021) 
Characteristics of the urban environment in and issues in the creation of a green shield around the city of Makhachkala, Dagestan, Russia

All-Russia People's Front, it has been recommended to devote more attention to the issue of slowness in surveying the city's forest-and-park areas and explore the possibility of including Eltav Forest in the list of public areas to be beautified as part of the municipal program 'Building a Modern Urban Environment ${ }^{\prime 13}$.

The city of Makhachkala stretches from the northwest to the southeast along the coast of the Caspian Sea. The city is planned in such a way that there are four major geographic reference points to focus on - northwestern, northeastern, southeastern, and southwestern. Accordingly, the major sites within the "green shield" tied to the geo-environmental landmarks in the capital of Dagestan are as follows: (1) Eltav Forest and the road to the township of Sulak - northwest; (2) the Caspian Sea with Makhachkala beaches - northeast; (3) Lake Ak-Gel and the road to the city of Derbent - southeast; (4) Tarki-Tau Mountain - southwest. These are the principal natural sites among the 33 elements in the green belt around the capital of Dagestan.

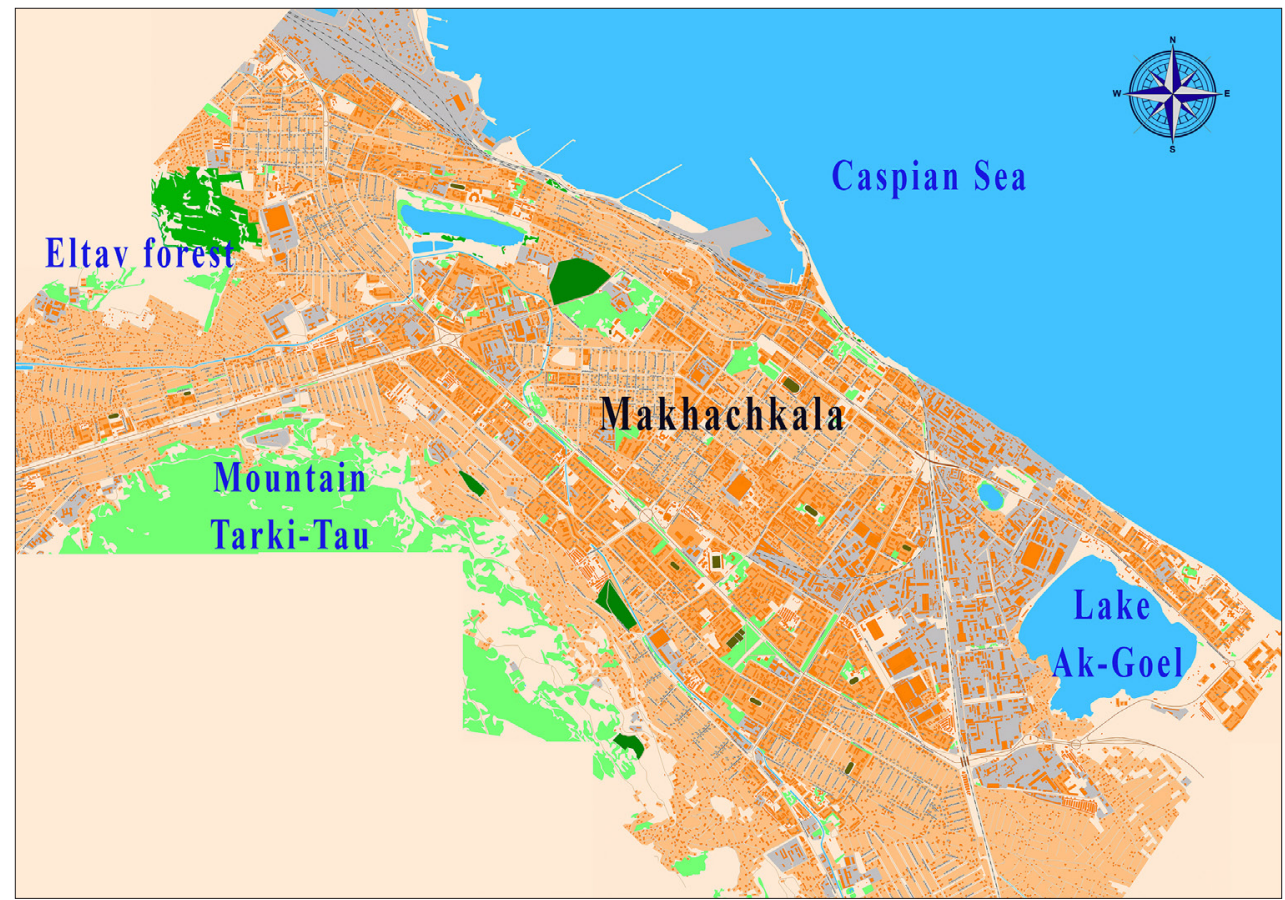

Figure 1. Key sites within the "green shield" around Makhachkala

13 Aktivisty ONF prizvali uskorit' protsess sozdaniya «zelonogo shchita» Makhachkaly [Elektronnyy resurs] // Obshcherossiyskiy narodnyy front. Novosti regionov. 18.01.2019. URL:https:/ / onf.ru/2019/01/18/aktivisty-onf-prizvali-uskorit-process-sozdaniyazelenogo-shchita-mahachkaly/ (data obrashcheniya 20.08.2021). 
Northwest (Eltav Forest and dune sands). The condition of Eltav Forest, a key site within the Makhachkala "green shield", is currently an area of concern for many residents of the capital. Specialists from the Mountain Botanical Garden of the Dagestan Federal Research Center of the Russian Academy of Sciences have warned that the forest may be doomed. However, they have also expressed the hope of a park area being established within its grounds (Asadulayev, 2019).

Several years ago, the ecosystem under examination was dealt a most powerful blow. To be specific, in 2014, construction work began on the outskirts of Eltav Forest to erect a multistoried house for rehoused tenants of derelict properties. This is quite a vivid example of how a noble cause can be adroitly used for nefarious purposes. Using forged documents, the crooks got hold of a large patch of land within the nature conservation area. Journalists later found out that in some cases the actions of the city's government and nature conservation authorities aimed allegedly at conserving Eltav Forest were in actuality nothing but a sham. While claims for ownership of the forest plots were legally filed, members of the city's administration were almost never present at the proceedings. Consequently, the lawsuits would end in favor of the crooks, who would just proceed with their "squatter" construction, showing hardly any remorse about the deforestation in the area.

It stands to reason that without addressing this kind of elaborate fraudulent land use schemes at a public level it will be difficult to create an ecologically sound urban environment in the city. At the same time, it must be remembered that Eltav Forest has been declared a protected natural area for the first time in the history of the capital, which has been accomplished thanks to the dedicated efforts of the current Mayor's Office. Despite the need for tight protection of the forest having been voiced by former government officials at all levels for many years, little headway had been made in resolving the issue, with the total area of plantings in Eltav Forest eventually shrinking over the last few decades by as much as 3 times, i.e. by 48 hectares of land.

What makes it doubly sad is the fact that in the 1930s immense work was carried out in the city to expand the natural area of this forest with the aim of protecting the capital from dust and sand storms from the north and northwest. Numerous windbreaks were created north of Makhachkala along the dune ridges on the coast of the Caspian Sea. Unfortunately, these dunes have been virtually razed to the ground over the last few decades. 
Characteristics of the urban environment in and issues in the creation of a green shield around the city of Makhachkala, Dagestan, Russia

The republic's nature conservation authorities keep turning a blind eye to the rampant extraction of sand for construction on the coast of the Caspian Sea both north of Makhachkala and on all of the republics seashores. The scale of this activity has been immense. Furthermore, it has been proven that the mining of redeposited sand formed by secondary wind deposition in maritime Dagestan is what is behind the process of progressive intensification of wind erosion (deflation) in the area, which in the end may lead to a worsening of the environmental and recreational situations along the foreshore (Aliyev, Sluka, Eldarov, 1993; Ignatov et al., 1995).

Given the above, there is a need to introduce, in a gradual manner, restrictions on the mining of dune and beach sand while searching for and using alternative sources of this material beyond the coastal area of the Caspian Sea. The potential for this is there. There are several proven quartz sand fields in the submontane area, and they are quite large. If need be, it may be possible to develop new fields in promising areas of alluvial sand along the Kizlyar to Karlanyurt rail line. As regards sea sand, it may be a good idea to reserve it for the purpose of conserving and improving the natural landscape in the recreational zone.

Northeast (Caspian Sea and Makhachkala beaches). The current projects on constructing centralized water disposal systems along the coast in the capital envisage the creation of four district water-treatment systems. Currently, just one such system is in operation (System 1); it handles the treatment of almost a third of the sewage produced in Makhachkala and Kaspiysk. The rest of the sewage is dumped into the sea without making it to the treatment facilities. The area where this kind of dumping mainly occurs is the northern part of the water area of a former out-of-town beach, where there is a deep-water collector for emergency discharge of the city's sewage water. The poorly built collector, which is located in the breaker zone, has incurred some serious damage over the years. As a result, highly concentrated sewage has for years spread along Makhachkala's entire coastal area over a large distance, all the way to the city's central beach ${ }^{14}$.

In the mid-1980s, the authorities developed a detailed plan for the second phase of construction of the sewerage network in the Makhachkala agglomeration. The project was launched on the eve of Perestroika (1989). It resulted in the construction of a $9.7 \mathrm{~km}$ long sewage collector $(65.5 \%$ of what was originally planned). That said, only 5 billion rubles worth of work was completed against a target of 9.6 billion. An analysis of the underground

\footnotetext{
14 Vodnyye resursy Dagestana: sostoyaniye i problemy. Makhachkala: ZK BVU, 1996.
} $180 \mathrm{~s}$. 
collector's condition conducted five years ago revealed a very poor quality of the work done, with flagrant violations of concrete pouring standards. Russia's Ministry of Construction, for reasons unknown, failed to provide the funding required to continue the construction of a tunnel to treatment facilities (2 billion rubles worth of work planned for 2016) (Abdulgamidov, 2016).

At the time the above scheme was being established, the nearshore areas of the capital of Dagestan and its satellite, the city of Kaspiysk, were receiving 350,000 cubic meters of sewage per day, with 200,000 cubic meters (70-75 million cubic meters per year) of this being untreated sewage. If expressed in terms of the prices of that period, the cost of the work left to complete was over 100 billion rubles. Taking into account the real growth of the actual agglomeration, expenditure on completing the construction of the city's entire drainage system was to be no less than 0.5 trillion rubles. Currently, the government is considering only a minimum funding threshold of 100 billion rubles.

The centralized water supply and sewage networks in Makhachkala's coastal area must serve not only the actual city but also the numerous recreational facilities along the coast of the Caspian Sea. The northern section stretches from the city of Makhachkala to the River Krivaya Balka, and the southern one - from the capital to the city of Izberbash. It appears to be advisable for the owners of these resorts to pool resources to fund the construction of water systems that will be in shared use among them (Borodina, 2017; Eldarov, Sluka, 1994).

The wellbeing of this maritime city is largely dependent on the level of development of its port complex. In just about any civilized country, the seaport is associated with the fish market. For instance, in Istanbul the fish market is located right on the seafront. Fish can be purchased there from mobile stands; you can have it fried and enjoy it at a table on site. Most maritime cities live the sea, tourism, fisheries, tankers, dry-cargo vessels, container ships liners, cruisers, ferries, large and small yachts, sailboarding, kitesurfing, paddleboarding, wakeboarding, small boats, barks, karbasses, motorboats, berths, piers, wharves, etc. and that is natural (Babchenko, 2013).

By contrast, right now the Makhachkala port is an empty, lifeless place. As is currently the case with the majority of Russia's port cities, nobody rents a berth and there are no yachts laying off here. You will not hear music playing on cruise liners here; nor will you come here across much buzzing activity in the form of passengers embarking into little recreation boats or 
Characteristics of the urban environment in and issues in the creation of a green shield around the city of Makhachkala, Dagestan, Russia

the morning's catch being unloaded. You will not find here anything but the military, the Customs, and the maritime police (Babchenko, 2013).

Southeast (Lake Ak-Gel). Lake Ak-Gel, situated on the southeastern outskirts of the capital of Dagestan, is quite a deep freshwater body of lagoonal origin, with an area of over 1 square kilometers. The lake lies virtually in the heart of the developing Makhachkala agglomeration. Surrounded by numerous residential and industrial properties, it is exposed to high levels of human-induced impact. The industrial and transportation complex enterprises operating in the lake's vicinity often dump toxic wastewater into it. As a result, most of its once abundant ichthyofauna is now gone. The lake has long been ignored by birds of passage, let alone resident fowl.

As a result of uncontrolled construction activity in the area, the lake's littoral and water conservation zones are pretty much gone now. Today's Lake Ak-Gel is a waterbody left without natural self-reproduction and selfcleansing mechanisms. A rivulet that once ran into it from the township of Tarki has been used as a sewage collector for a long time now (Tsapiyeva, Denevizyuk, 2013).

The city's former leadership desired to backfill Lake Ak-Gel, Makhachkala's largest natural waterbody, with the aim of selling a set of pricey plots of land in the area. Luckily, thanks to vehement protesting on the part of the city's general public, the project was scrubbed. Having said that, the littoral zone continues to be a place where multistoried buildings and constructions of varying function are built. There is a need to work on the issue of integrated development of Lake Ak-Gel and areas around it in a most dedicated manner.

Restoring the lake environmentally will require artificial water supply, removing all sources of polluting runoff into it, fish propagation programs, developing children's yachting, and developing other eco-friendly types of water recreation. Of importance is the creation of a sound legal framework that will counteract illegal seizure of protected lakeside land. Every effort must be made to bring to justice dishonest officials and entrepreneurs who, under the specious pretense of beautifying an area of public use, seek to carry out their own business projects without much regard for the environmental and aesthetic effect that kind of activity can have on the site. In other words, when it comes to resolving nature conservation issues affecting Ak-Gel, it is important to try and see the "hidden hazards" that the municipal government is unable to tackle on its own without the help of the general public. 
With that said, the actions of those in charge of the municipal government must be coordinated as much as possible with the interests and initiatives of representatives of the city's nongovernmental environmental organizations.

The above idea is clearly illustrated by the story of a project aimed to build a church on the shore of this lake, which was being persistently pushed through by a group of officials and entrepreneurs. The effort was soon exposed as a fraud by residents of Makhachkala, with the fraudulent plan found to be as follows: build an Orthodox Christian temple in order to morally justify the construction activity in the lake's water conservation and protected shoreline areas, which was being carried out in flagrant violation of Russia's Water Code. A community of caring individuals quickly emerged in the capital to defend the lake. Of note is the fact that the majority of this group were ethnic Russians permanently residing in Makhachkala (Makhmudova, 2018).

The current plan for integrated beautification of the park around AkGel is being considered in conjunction with creating a large environmental site not far from it - a public area starting near the Prophet Isa Ecclesiasticaland-Educational Center and ending on the coast of the sea. However, in implementing the project, the authorities have been faced with the issue of having to regain hold of certain plots previously purchased by private individuals for construction purposes, a problem that requires looking for ways to prevent potential conflicts in the area of urban land use (Ionov, 2020; Eldarov, 2020).

Southwest (Tarki-Tau Mountain). Discussions around issues of ecological development of the capital's suburban zone tend to begin in recent years with the topic of acute conflicts in the area of land use around Tarki-Tau Mountain. The key cause behind them is that the government has long paid little attention to issues of building in and making recreational use of these areas, which has led to the local community addressing them in a resolute, and at times even aggressive, manner. Over the last 15 years, activists representing the townships Tarki, Kyakhulai, and Alburikent have mounted a loud protest against the freewheeling recreational use of the mountain by Makhachkala residents. In particular, they have spoken out against bonfires on the slopes of Tarki-Tau Mountain, pits used as improvised braziers, crowded outdoor parties, etc., arguing that activities of this kind should be held only with permission from the council of elders in the settlements (Sluka, Tikunov, Chereshnia, 2019). 
Characteristics of the urban environment in and issues in the creation of a green shield around the city of Makhachkala, Dagestan, Russia

There are many areas on the slope of Tarki-Tau Mountain that back in the Soviet era were designated for afforestation. Today, most of them are treeless plots that are rented out to anyone willing to use them. However, profit from renting these plots out can never justify the damage their use is causing to the area's environment. The issue worthy of special consideration is construction activity in landslide hazard areas on the mountain's piedmont slopes.

The aggressive behavior displayed by residents of Tarki, Kyakhulai, and Alburikent is a sign of frustration boiling over in the region, as their appeals have been left unanswered by the authorities. Therefore, it is important that Makhachkala residents know the real cause behind the exacerbation of both nature conservation and ethnopolitical issues in the area, which is the failure of the authorities to provide a constructive response to the fair and lawful demands of the Tarki council of elders.

There have been numerous cases of construction activity being carried out on the landslide hazard slopes of Tarki-Tau Mountain. Future climatic changes in the Caspian Sea region that are expected to result in colder and more humid weather may naturally galvanize landslide processes, which, in turn, may lead to the destruction of homes in the place's piedmont areas and endanger the lives of their residents.

Thus, one can only rejoice in the robust nature conservation efforts by the councils of elders in settlements near Tarki-Tau Mountain. The residents are perfectly aware of the fact that their natural environment is something they inherited from past generations, so they must treat the cause of conserving and protecting it as a sacred one.

\section{Conclusion}

Rectifying the critical condition of the environment in the capital of Dagestan, Makhachkala, will require a raft of urgent measures to be taken based on creative decisions made taking into account the city's distinctive geographic-environmental and socio-economic characteristics. Furthermore, given Dagestan's multiethnic makeup, it will be important to take into account the diversity of its ethnocultural traditions of natural resource use. In particular, it will help to launch at a legislative level the process of reviving the centuries-old laws and norms on natural resource use that are well adapted to the mentality, traditions, and customs of Dagestan's mountainous peoples. However, for now Dagestanis will have to be guided exclusively by common federal laws, most of which do not take account of 
local characteristics. The current legal situation may be fraught with serious implications for the environment of the Country of Mountains.

\section{References}

Abdulgamidov A. Tupik $\mathrm{v}$ kontse tonnelya? [Elektronnyy resurs] // Gazeta "Chernovik". 14.10.2016. URL: https://chernovik.net/content/ respublika/tupik-v-konce-tonnelya (data obrashcheniya 20.08.2021).

Aktivisty ONF prizvali uskorit' protsess sozdaniya "zelonogo shchita" Makhachkaly [Elektronnyy resurs] // Obshcherossiyskiy narodnyy front. Novosti regionov. 18.01.2019. URL: https://onf.ru/2019/01/18/ aktivisty-onf-prizvali-uskorit-process-sozdaniya-zelenogo-shchitamahachkaly/ (data obrashcheniya 20.08.2021).

Aliyev D. R., Sluka N. A., Eldarov E. M. Primorskiy Dagestan: problemy i perspektivy. Makhachkala: Dag. TSNTI, 1993. $144 \mathrm{~s}$.

Antonov Ye. $V$., Makhrova A. G. Krupneyshiye gorodskiye aglomeratsii i formy rasseleniya nadaglomeratsionnogo urovnya v Rossii / / Izv. RAN. Ser. geografich. 2019. No4. S. 31-45.

Asadulayev Z. M. Kiparisovyy Derbent i obrechonnyy El'tavskiy les: oshibki i tragedii glazami botaniki [Elektronnyy resurs] // RIA "Derbent". 25.05.2019. URL: https://riaderbent.ru/kiparisovyj-derbent-iobrechennyj-eltavskij-les-oshibki-i-tragedii-glazami-botaniki.html?utm_ source =yxnews\&utm_medium=desktop (data obrashcheniya 20.08.2021).

Aliyev T. Mera dlya mera. Meru Makhachkaly grozit pyat' let kolonii [Elektronnyy resurs] // Rossiyskaya gazeta. 04.10.2018. URL: https:// rg.ru/2018/10/04/reg-skfo/meru-mahachkaly-grozit-piat-let-kolonii. html (data obrashcheniya 20.08.2021).

Akhmedov T. Kogda pridut za Moryakom? [Elektronnyy resurs] // Kavpolit. 10.03.2016. URL: http://kavpolit.com/blogs/ostanovitkorrypciy/24856 (data obrashcheniya 20.08.2021).

Babchenko A. Mortvoye mesto [Elektronnyy resurs] // COLTA.RU. Obshchestvo. 18.11.2013. URL: https://www.colta.ru/articles/ society/1205-mertvoe-mesto (data obrashcheniya 20.08.2021).

Bagomedov M. A. Sotsial'no-demograficheskiye problemy razvitiya Makhachkalinsko-Kaspiyskoy aglomeratsii // Voprosy strukturizatsii ekonomiki. 2013. No4. S. 8-12. 
Characteristics of the urban environment in and issues in the creation of a green shield around the city of Makhachkala, Dagestan, Russia

Borodina T. L. Regional'nyye osobennosti dinamiki naseleniya Rossii v postsovetskiy period / / Izv. RAN. Ser. geogr. 2017. No1. S. 47-61.

Vodnyye resursy Dagestana: sostoyaniye i problemy. Makhachkala: ZK BVU, 1996. $180 \mathrm{~s}$.

Gadzhiyev N. G., Rabadanov M. Kh., Eldarov E. M. Kaspiyskiy transportnyy uzel i geoekonomicheskaya strategiya Dagestana // Nauchnoye obozreniye: teoriya i praktika. 2017. No7. S. 13-21.

Gosduma prinyala vo vtorom i tret'yem chtenii zakonoproyekt ONF o «zelonom shchite» [Elektronnyy resurs] // Obshcherossiyskiy narodnyy front. 17.06.2016. URL: https://onf.ru/2016/06/17/gosduma-prinyalavo-vtorom-i-tretem-chtenii-zakonoproekt-onf-o-zelenom-shchite/ (data obrashcheniya 20.08.2021).

Gosudarstvennyy doklad “O sanitarno-epidemiologicheskoy obstanovke v RD v 1995 godu" / Otv. red. E. YA. Omariyeva. Makhachkala, 1995. 114 s.

Gosudarstvennyy doklad "O sanitarno-epidemiologicheskoy obstanovke v RD v 2018 godu" / Otv. red. E. YA. Omariyeva. Makhachkala, 2019. 135 s.

Dagestan $\mathrm{v}$ autsayderakh po sozdaniyu zelonogo shchita [Elektronnyy resurs] // Gazeta "Chernovik". 02.06.2019. URL: https://chernovik. net/content/lenta-novostey/dagestan-v-autsayderah-po-sozdaniyuzelenogo-shchita (data obrashcheniya 20.08.2021)

Demograficheskiy yezhegodnik. 2002 god. Stat. sbornik. Makhachkala: Goskomstat RD, 2003. $192 \mathrm{s.}$

Dagestan na putiv budushcheye: sotsial'no-ekonomicheskiye preobrazovaniya / Sagidov Yu. N. i dr. Makhachkala: DNTS RAN, 1996. 175 s.

Doklad o sostoyanii okruzhayushchey prirodnoy sredy Respubliki Dagestan v 2001 godu. Makhachkala: Izd-vo "Yupiter", 2002. 224 s.

Dolgikh Ye. I., Antonov Ye. V. Reyting ustoychivogo razvitiya rossiyskikh gorodov [Elektronnyy resurs] // Demoskop Weekly. 2015. No631-632. URL: http://demoscope.ru/weekly/2015/0631/tema01.php (data obrashcheniya 20.08.2021).

Zubarevich N. V., Safronov S. G. Razvitiye bol'shikh gorodov v Rossii v 2000kh godakh // Regional'nyye issledovaniya. 2019. No1. S. 39-51.

Ignatov Ye. I., Rychagov G. I., Safyanov G. A., Badyukova Ye. N., Varushchenko A. N., Solovyeva G. D. Sotsial'no-ekologicheskiye posledstviya pod"yoma 
urovnya Kaspiyskogo morya $\mathrm{v}$ predelakh gorodskikh territoriy rossiyskogo poberezh'ya // Ekologicheskiye aspekty teoreticheskoy i prikladnoy geomorfologii. 3-i Shchukinskiye chteniya. M.: MGU, 1995. S. 221-224.

Ionov O. Muftiyat Dagestana potreboval nakazat' avtorov soobshcheniy o zemle dlya dukhovnogo tsentra [Elektronnyy resurs] // Gazeta "Kavkazskiy Uzel" ot 25.12.2020. URL: https://www.kavkaz-uzel.eu/ articles/357994/ (data obrashcheniya 20.08.2021).

Kirilova P. L., Makhrova A. G. Opyt tipologii regional'nykh sistem gorodskogo rasseleniya Rossii / / Regional'nyye issledovaniya. 2020. No1. S. 4-15.

Kotilko V. V., Pashayev M. E., Vinogradov D. V., Matiyenko I. V., Mugulov F. K., Magomedov Kh. A., Shulayev V. V., Kibal'nikov D. S., Tyukov A. P., Khalilov Kh. Sh. Kak budet vyglyadet' Makhachkala budushchego? [Elektronnyy resurs] // Dagestan. Argumenty i Fakty. 22.04.2019. URL: https:// dag. aif.ru/society/kak_budet_vyglyadet_mahachkala_budushchego (data obrashcheniya 20.08.2021)

Kots A. Kak byla ustroyena imperiya kavkazskogo «Krovavogo Ruzvel'ta» [Elektronnyy resurs] // 10.06.2013. URL: https://www.kp.ru/ daily/26089.5/2990488/ (data obrashcheniya 20.08.2021).

Kuzmina $V$. N. Dagestan protiv musora: ot passivnogo k aktivnomu protestu // Regional'nyye aspekty sotsial'noy politiki. No22. C. 133-139

Magomayev T. N. Fiziologiya Semendera // Trudy Geograficheskogo obshchestva RD. 2014. No42. S. 90-95.

Makhmudova P. Aktivisty obvinili silovikov v sryve aktsii protiv stroitel'stva khrama v Makhachkale [Elektronnyy resurs] // Gazeta "Kavkazskiy Uzel" ot 07.05.2018. URL: https://www.kavkaz-uzel.eu/articles/320140/ (data obrashcheniya 20.08.2021).

Mediko-gigiyenicheskiy atlas Respubliki Dagestan / otv. red. E.YA. Omariyeva, E. M. El'darov. Makhachkala: Poligraf-servis, 2002. 132 s.

Naseleniye SSSR: Po dannym Vsesoyuznoy perepisi naseleniya 1989 g. / Gos. komitet SSSR po statistike. Informatsionno-izdatel'skiy otdel. M.: Finansy i statistika, 1990. 45 s.

Pokazateli sostoyaniya zdorov'ya naseleniya RD v 2015 godu. Makhachkala: Minzdrav RD, 2016. 317 s. 33. Rybina YU. Gradonachal'nik popalsya na auktsione [Elektronnyy resurs] // Kommersant". 07.11.2018. URL: 
Characteristics of the urban environment in and issues in the creation of a green shield around the city of Makhachkala, Dagestan, Russia

https://www.kommersant.ru/doc/3793286 (data obrashcheniya 20.08.2021).

Sarkarov A. Z. Demograficheskaya dinamika Dagestana v posleperepisnoy period 2010-2017 godov // Regional'nyye aspekty sotsial'noy politiki. 2017. No19. S. 51-60.

Sovremennyye ekologicheskiye problemy Dagestana. Makhachkala: DGPU, 1994. $198 \mathrm{~s}$.

Tsapiyeva O. K., Denevizyuk D. A. Sotsial'nyye faktory ustoychivogo razvitiya goroda (na primere goroda Makhachkaly) // Problemy sovremennoy ekonomiki. 2013. No3 (47). S. 319-323.

Chernyshov M. M. Strategiya sotsial'no-ekonomicheskogo razvitiya Respubliki Dagestan do 2025 goda: voprosy sotsial'noy geografii // Trudy Geograficheskogo obshchestva Respubliki Dagestan. 2012. № 40. S. 69-75.

Eldarov E. M., Sluka N. A. Okruzhayushchaya sreda stolitsy Dagestana. Glava 4 / / Sovremennyye ekologicheskiye problemy Dagestana. Makhachkala: DGPU, 1994. S. 71-80.

Eldarov E. M. Sotsial'no-politicheskiye i etnopsikhologicheskiye voprosy prirodopol'zovaniya v Makhachkale / / Regional'nyye aspekty sotsial'noy politiki. 2020. No22. S. 118-132.

Eldarov E. M. Tarki-Tau razdora i dzhamaat Tarkov: agressivnost' budet narastat' (Interv'yu A.Sarkarova) [Elektronnyy resurs] / / RIA “Derbent". 16.02.2020. URL: https://riaderbent.ru/tarki-tau-razdora-i-dzhamaattarkov-agressivnost-budet-narastat.html (data obrashcheniya 20.08.2021).

Sluka N. A., Tikunov V. S., Chereshnia O. Y. The geographical size index for ranking and typology of cities / / Social Indicators Research. 2019. No144 (2). C. 981-997. 